\title{
Wykorzystanie techniki infuzji do budowy podobrazi pomocniczych na przykładzie obrazu Aleksandra Kobzdeja Hors cadre $\mathrm{Nr} 53$
}

Od kilkunastu już lat prowadzone są szerzej zakrojone badania i prace konserwatorskie przy obrazach stanowiących spuściznę Aleksandra Kobzdeja ${ }^{1}$. Wiele bardzo interesujących z punktu widzenia problematyki badawczej wątków zostało poruszonych ${ }^{2}$, jednak problematyka konserwatorska tych dzieł nieustannie odkrywa przed nami nowe tematy rozważań i skłania do dalszych poszukiwań. Zaczynamy zadawać sobie pytanie: czy sztuka nowoczesna stawia przed konserwatorami zbyt wygórowane wymagania? Postulat posługiwania się najlepszymi materiałami i wiedzą oparta o najnowsze odkrycia nauki oraz zdobycze techniki dawniej stanowił kierunek wytyczony przez najbardziej szanowane gre-

1 Pierwsze prace autor miał sposobność wykonywać z M. Matuszczykiem i D. Markowskim w roku 2003 przy obrazie Nr 15 Duett in weiss, a podstawa artykułu sa prace przeprowadzone w ramach zajęć dyplomowych pod kierunkiem prof. dr. hab. D. Markowskiego i dr. S. A. Kamińskiego przez A. Cwynar przy obrazie Hors Cadre nr 53 (A. Cwynar, Dokumentacja prac konserwatorskich i restauratorskich. Obraz. Hors Cadre nr 53 Aleksandra Kobzdeja ze zbiorów Muzeum Okręgowego im. Leona Wyczółkowskiego w Bydgoszczy. Praca dyplomowa, ZKiRSzN, MK, Toruń 2012).

2 Np. problemem korozji elementów metalowych w obrazach współczesnych zajmował się M. Matuszczyk w Konserwacja malarstwa wspótczesnego z elementami metalowymi w podtoín, praca doktorska pod kierunkiem dr. hab, J. Krauzego prof. UMK, UMK Toruń, 2005. 
mia, dzisiaj bez badań wykonanych na najwyższym z możliwych poziomów, z użyciem wysoko zaawansowanej techniki nie jesteśmy w stanie prawidłowo zdiagnozować: stanu zachowania, procesów zachodzących w dziełach sztuki nowoczesnej i w konsekwencji - przeprowadzić prawidłowo prac konserwatorskich. Napotykane problemy zmuszają do poszukiwania rozwiązań w dziedzinach wydawałoby się całkiem odległych, co poszerza warsztat konserwatorski w zgoła nieoczekiwanych kierun$\mathrm{kach}^{3}$. Takim przykładem wydaja się prace przy niestabilnych podobraziach ostatniego cyklu prac Aleksandra Kobzdeja - Hors cadre.

Aleksander Kobzdej - malarz, grafik, ilustrator, scenograf, architekt, nauczyciel akademicki (profesor Katedry Malarstwa w Akademii Sztuk Pięknych w Warszawie, w latach 1965-1966 prowadził również Katedrę Malarstwa w Hochschule für Bildende Kunste w Hamburgu), kolorysta i abstrakcjonista $z$ epizodem socrealistycznym (jednym z najbardziej znanych polskich obrazów z tego okresu jest jego praca Podaj cegłe z 1950 r.) po politycznej odwilży odszedł od przedstawień figuralnych i wrócił do tworzenia abstrakcji, odnajdujący się, nie bez sukcesów, w nurcie informel. To jeden z tych polskich artystów działających po wojnie, który w swojej twórczości bez kompleksów umiejętnie wchodził w polemikę z najważniejszymi nurtami sztuki światowej (jej czołowych twórców bardzo często znał osobiście), umieszczając swoje prace w wielu znanych kolekcjach ${ }^{4}$. Przedmiotem jego artystycznych poszukiwań stała się materia przesycona swoistą duchowością i mistyka. Pod wpływem podróży na Daleki Wschód eksperymentował z malarstwem kaligraficznym, potem przyszedł czas na wywodzące się z malarstwa gestu Gęstwiny, w końcu powstał nagrodzony w 1959 na biennale w São Paulo metaforyczny,

3 Patrz: S. A. Kamiński, Konserwacja zapobiegawcza wybranych obrazów wspótczesnych. Ograniczenia i perspektywy [w:] Konserwacja zapobiegawcza w muzeach, pod red. D. Folgi-Januszewskiej, Warszawa 2007, ss. 242-264.

4 Prace A. Kobzdeja znajduja się w wielu zbiorach w Polsce i na świecie, m.in. w: Muzeach Narodowych w Warszawie i Krakowie, Muzeum Sztuki w Lodzi, The Museum of Modern Art w Nowym Jorku, The Guggenheim Museum w Nowym Jorku, Moderna Muséet w Sztokholmie, Musée d'Art Moderne w São Paulo, Rockefeller Collection, USA, G. David Thompson Collection, USA. 
utrzymany w dramatycznym nastroju, zadziwiający kolorystycznym smakiem cykl Idole, w których podkreślał materialny status i rangę samej farby, różnicując fakturę kompozycji i eksponując niuanse kolorystyczne ${ }^{5}$. W kolejnych cyklach coraz mocniej wykraczał poza granicę tradycyjnego malarstwa. W latach 60. stworzył najodważniej przekraczające płaszczyznę Szczeliny, łączące w sobie cechy kompozycji płaszczyznowej, inspirowanej nurtem colour fields painting, z reliefami, które z jednej strony są swego rodzaju kontinuum zagadnień malarstwa materii, z drugiej zaś stanowią naturalne przeciwieństwo i konkurencję dla kolorowych płaszczyzn, przekraczając ich ograniczenia (fot. 1). Na początku następnej dekady w cyklu Hors cadre zerwal ostatecznie $\mathrm{z}$ tradycyjnym podobraziem, wchodząc w organicznie modelowana przestrzeń - stworzył kilkadziesiąt niezwykle oryginalnych malarsko-rzeźbiarskich struktur - konstrukcji formowanych z plastycznej masy papierowej jakby „udrapowanej” na metalowej siatce, w Szczelinach wykorzystywanej często do konstruowania skomplikowanych podobrazi wieloelementowych. Uwolnił się w ten sposób od dychotomii poprzedniego cyklu, w którym antagonizował płaszczyzny ze strukturami przestrzennymi i wykorzystując charakter wybranej materii, tym razem szanował, jak sam wspomina, jej ograniczenia ${ }^{6}$. Można zaryzykować twierdzenie, że po szaleństwie Szrzelin wykonał zwrot w kierunku malarstwa rozumianego tradycyjnie, lekko tylko zadrażniającego przestrzeń za pomoca podobrazi o delikatnie modelowanym kształcie, przywodzących na myśl formy organiczne, odchodząc od stosowania krosien, twardych płyt oraz różnych drobnych form łączonych ze sobą w intrygujący sposób. Jak sam stwierdził: „kończy zabawę z porządkowaniem prostokąta” i rozpoczął poszukiwania w świecie nowych, mniej dramatycznych rozwiązań formalnych. Cykl Hors cadre powstawał na przełomie 1970 i $1971 \mathrm{roku}^{7}$. Sposób operowania organicznymi formami przestrzennymi przywodzi na

5 Aleksander Kobżdej - zmagania z. materia, katalog pod red. J. Grabskiego, Kraków-Warszawa 2002.

6 A. Kobzdej, Drogi gościu! [w:] Aleksander Kobzdej - zmagania z. materiq..., s. 97-110.

7 Żona Artysty Maryna Kobzdej twierdzi, że początek prac nad cyklem Hors cadre sięgają roku 1969 (wywiad z żoną A. Kobzdeja na temat jego twórczości [w:] I Szmelter, M. Jadzińska, Zachować dla przyszłłości - artyści warszawscy, film na CD, ASP Warszawa, 2003). 
myśl rzeźbiarskie poszukiwania przyjaciela Kobzdeja - Henry’ego Moore’a, natomiast kolorystyka - rozwibrowana i wysmakowana - wywodzi się wyraźnie z kręgu op art, jakby inspirowana twórczością zmarłego w 1970 roku Marka Rothko - może prace te stanowiły swego rodzaju artystyczne epitafium dla poznanego podczas wizyty w Stanach Zjednoczonych słynnego kolegi. Tego niestety się już nie dowiemy - Kobzdej zmarł nagle w roku 1972, a cykl Hors cadre nie doczekal się w związku z tym należytej promocji, artysta nie zdążył też wyjaśnić do końca wszystkich wątków związanych z powstawaniem prac. Pojedyncze dzieła trafily po śmierci artysty do kilku polskich muzeów, ale do dzisiejszego dnia w jego pracowni znajduje się duża liczba niewystawianych wcześniej obrazów.

Z punktu widzenia budowy technicznej Hors cadre to kilkadziesiąt delikatnych prac, skonstruowanych z pozoru w bardzo prosty sposób, lecz o niezwykle skomplikowanej problematyce konserwatorskiej. Osadzone w nurcie minimal art Horse Cadre nie mają tytułów - jedynie numery, nie mają krosien i zgodnie z nazwą cyklu - ram (konstrukcja podobrazia w zamyśle artysty miała być samonośna). Włączanie przestrzeni w świat malarstwa, jak wspomniano wyżej, rozpoczęło się u Kobzdeja już w poprzednich cyklach ${ }^{8}$. Najbogatszym pod tym względem oraz najbardziej zróżnicowanym materiałowo były Szczeliny - zdobyte przy ich tworzeniu doświadczenia w przestrzennym formowaniu różnego rodzaju materii widoczne są również wyraźnie w omawianym cyklu. Jako rdzenia podobrazia artysta użył tutaj kształtowanej przestrzennie, drucianej siatki, we wcześniejszych pracach materiał ten stanowił rdzeń jednego lub kilku elementów tworzących bardziej złożoną kompozycję, unieruchomionego poprzez zamocowanie do części sztywnych: listew, płyt, krosien lub - jak w minicyklu Wgłębienia ${ }^{9}$ - ram. W cyklu Hors cadre artysta

8 S. A. Kamiński, Problematyka konserwatorska nowoczesnego warsztatu malarskiego na prayketadzie wybranych dziet Aleksandra Konzdeja. Obrazy przestrzenne, [w:] D. Markowski, S. A. Kamiński, M. Wachowiak, Wybrane zagadnienia konserwacji i restauracji sztuki nowoczesnej, Toruń 2010, ss. $159-191$.

9 S. A. Kamiński, Problematyka konserwatorska nowoczesnego warsztatu malarskiego na przyketadzie wybranych dziet Aleksandra Konzdeja. Prace konserwatorskie i restauratorskie, [w:] D. Markowski, S. A. Kamiński, M. Wachowiak, Wybrane zagadnienia..., ss. 191-213. 
po raz kolejny na nowo formułuje koncepcje przestrzennego podobrazia malarskiego i zachowując dotychczasową swobodę indywidualnej kreacji kształtu podobrazia każdej pracy, upraszcza ich budowę. Dzięki drastycznemu ograniczeniu liczby elementów ${ }^{10}$ składających się na każdą pracę udaje mu się uzyskać większą niż do tej pory lapidarność dzieł należących do jednego cyklu, zachowując indywidualny charakter poszczególnych obrazów. Używając siatki jako rdzenia, początkowo kładł na nia papièr maché, być może jednak pojawiające się na powierzchni prac (często siatka wykonana była z niecynkowanego drutu), przebarwiające warstwę malarską rdzawe plamy skłoniły artystę do modyfikacji techniki i sięgnięcia po spoiwa niezawierające wody. Potem na wyprofilowaną siatkę artysta nakładał laminat poliestrowo-celulozowy w taki sposób, aby jego najwyższe warstwy mogły stanowić chłonne podobrazie dla (najczęściej) gwaszy ${ }^{11}$ delikatnie różnicowanych tonalnie, przeważnie prawie monochromatycznych, o wyraźnie zdefiniowanej kolorystyce. Mieszał zwykle nie więcej niż trzy odcienie tego samego koloru, jaskrawe i nasycone w barwie, wyjątkowo zestawiane z jasną biela (obecnie żółtawą szarościa) „surowej” ligniny lub jakimś wyszukanym akcentem kolorystycznym spoza gamy. Głęboko matowe obrazy o chropowatej powierzchni oryginalnie nie były werniksowane. Ich budowa techniczna to swego rodzaju eksperyment malarski.

Jedną z charakterystycznych cech twórczości Kobzdeja było sprawne posługiwanie się szerokim wachlarzem różnych technik artystycznych i pozaartystycznych, ze skłonnością do łączenia ich ze sobą w jednym obiekcie. W każdym z kolejnych cykli artysta używał odmiennych środ-

10 W Szczelinach, zależnie od stopnia skomplikowania, liczba elementów, z których wykonano podobrazie, wahała się od kilkunastu do kilkudziesięciu, Horse cadre zwykle składały się z trzech do maksymalnie dziesięciu - w przypadku obrazów, w których artysta użył kilku brytów siatki zamiast jednego (format).

11 W ZKiRSzN prowadzone były próby odtworzenia takiego laminatu z chłonną warstwą wierzchnia - prace wykonywała A. Chenc w ramach pracy dyplomowej Forma przestrzenna, abstrakicja niegeometryczৃna, „Kompozycja różowa”, A. Kobżdej, 1968, Mužeum Narodowe w Poznaniu, pod kierunkiem prof. dr. hab. D. Markowskiego, dr. S. A. Kamińskiego i dr. M. Wachowiaka, ZKiRSzN, UMK, Toruń 2015. 
ków wyrazu, niekiedy znajdując je bardzo daleko od tradycyjnego warsztatu malarskiego. W historii rozwoju technik malarskich można znaleźć wiele przykładów poszukiwań nowych środków wyrazu poza dopracowywanym przez pokolenia warsztatem, a poszukiwania takie niekiedy wiązały się z powstawaniem mniej lub bardziej odwracalnych zniszczeń w pewnych partiach lub nawet utrata całego dzieła ${ }^{12}$. Wspomniane na początku badania ${ }^{13}$ pozwoliły określić odrębna problematykę konserwatorską każdego cyklu, która w dużej mierze wiązała się z budową techniczną obrazów. W przypadku Hors cadre problemy konserwatorskie nie wynikają z odejścia od wypracowanej techniki, raczej należą do kategorii dobrze znanej, np. ze świata motoryzacji „błędów wieku dziecięcego". Charakterystyczne dla cyklu materiały były już od wielu lat używane przez artystę na różne sposoby w Squželinach i Wgłębieniach, nowościa jest ich całkowita autonomia. Wykształcony technicznie artysta bardzo szybko dostrzegł problemy wynikające z zastosowania nowego typu podobrazia. Szczególnie w odniesieniu do obrazów o większych formatach powstałe dzieła okazały się znacznie delikatniejsze od tradycyjnych, a ekstremalna niestabilność kształtu ${ }^{14} \mathrm{w}$ niektórych przypadkach właściwie wykluczała ich bezpieczne eksponowanie, transport czy przechowywanie. Faktycznie artyście udało się dotrzeć w swoich poszu-

12 Np. szeroko znana „porażka” Leonarda da Vinci - malowidło „Bitwa pod Anghiari” z 1. 1503-06 zlecone przez Signorię do Sali Rady w Palazzo Vecchio we Florencji dzięki znajomości Leonarda z Niccolò Machiavellim. Według części źródeł dzieło nigdy nie zostało zrealizowane, powstał jedynie karton (który uległ zniszczeniu bądź zaginą). Według badań Irvinga Stone’a do swej książki o Michale Aniele „Udręka i ekstaza” (dokonanych pod kierunkiem i dzięki pomocy naukowców takich jak B. Bernson, L. Goldscheider, A. Fortuna, dr U. Middledorf) malowidło zostało zrealizowane przez Leonarda, lecz uległo zniszczeniu w wyniku użycia przez artysty mikstury opisanej przez Pliniusza, która miała umożliwić wydłużenie czasu pracy. Zmieszał on wosk z rozpuszczalnikiem oraz guma arabska, a następnie składniki te poddał działaniu gorąca, co spowodowało spłynięcie farb (I. Stone, Udreka i elestaza, Czytelnik, Warszawa 1990).

13 Szerzej w: S. A. Kamiński, „Problematyka technologiczna i konserwatorska malarstwa Aleksandra Kobzdeja”, rozprawa doktorska, UMK Toruń 2007, mps.

14 A. Warszewska, ,Podłoża konstrukcyjne dla obiektów niestabilnych, o niskiej sztywności na przykładzie Hors cadre nr 38 i 44 Aleksandra Kobzdeja”, praca magisterska pod kier. prof. dr. hab. D. Markowskiego i dr. S. A. Kamińskiego, UMK Toruń, 2009, mps. 
kiwaniach do skraju możliwości materii, osiagając jednocześnie niespotykaną do tej pory w naszym środowisku artystycznym lapidarność języka malarskiego, tkwiąca korzeniami w minimal art. Obserwując niekorzystne cechy powstałych niestabilnych podobrazi, Artysta razem ze swoimi asystentami i studentami rozpoczął wprowadzanie modyfikacji konstrukcyjnych - w kilku pracach dolaminował od odwrocia dodatkowe wręgi poliestrowo-szklane (przykładem może być omawiany poniżej Hors cadre №38) - ich zadaniem było zwiększenie sztywności podobrazi i umożliwienie bezpiecznej ekspozycji prac w pozycji wiszącej ${ }^{15}$. Na odwrocie gotowej pracy kładziono gumowy wąz o średnicy około $2 \mathrm{~cm}$, następnie posługując się żywica poliestrową i matą szklaną o niezbyt wysokiej gramaturze wąż oblaminowywano. Po zżelowaniu żywicy i wyciagnięciu węża uzyskano dolaminowaną w górnej partii odwrocia poprzeczną wręgę, charakteryzująca się niską masą i znaczną sztywnością, częściowo stabilizująca kształt podobrazia, dodatkowo umożliwiała ona bez ingerencji (wykonywanie otworów od lica, przez warstwę malarska) zamontowanie drutu, pozwalającego w bezpieczny sposób eksponować obraz. Tak wykonane w kilku pracach wzmocnienia w górnej, a czasami również w dolnej części, jak się jednak z czasem okazało tylko częściowo stabilizujacc, wpływały na powstawanie niekorzystnych deformacji podobrazi, np. podczas nieprawidłowego przechowywania. Zwiększały masę obrazu, zmieniając położenie środka ciężkości, powodowały powstawanie deformacji na granicy tej części podobrazia, która pozostawała nieusztywniona (głównym czynnikiem mającym wpływ na stabilność tych podobrazi jest ich wielkość, niebagatelne znaczenie ma również kształt) ${ }^{16}$.

15 Sposób ich wykonania opisał jeden z pomagających wówczas Kobzdejowi studentów, obecnie profesor ASP w W-wie R. Strent (Wywiad z asystentami A. Kobzdeja - Rafałem Strentem i Jackiem Dyrzyńskim z [w:] I. Szmelter, M. Jadzińska, Zachowaí dla prayyszłości artyści warszawscy, film na CD, ASP M. Jadzińską i M. Matuszczyka, Warszawa 2003).

16 Obrazy mają taką samą konstrukcję - budowa siatek metalowych (grubość drutu, wielkość oczka, sposób przeplatania), grubość i parametry laminatu są zbliżone. Wystarczającą sztywność podobrazia bez tendencji do powstawania odkształceń dla tego typu konstrukcji można bez większego błędu oszacować na powierzchnię o kształcie kwadratu wielkości około $20 \mathrm{~cm}^{2}$, przy większym formacie dochodzą dodatkowe czynniki jak kształt, sposób, 
Problemy konstrukcyjne dzieł artystów posługujących się nowoczesnym warsztatem nie są bynajmniej wyjątkiem i dotyczą w mniejszym lub większym stopniu całkiem już sporej grupy prac nowoczesnych i współczesnych.

Obok niestabilności kształtu podobrazi w obrazach z cyklu Hors cadre spotykamy inne poważne problemy konserwatorskie, jak wspomniana korozja elementów metalowych, kruchość pękającego i odspajającego się laminatu, zmiany kolorystyczne nieodpornej na działanie światła warstwy malarskiej oraz łatwo osiadający kurz, trudna do oczyszczania, wrażliwa na działania mechaniczne i podwyższoną wilgotność oraz działanie UV porowata powierzchnia lica ${ }^{17}$, jak również odwrocia.

Rozważając kierunki działań konserwatorskich przy podobraziach Hors cadre, naturalne wydawało się kontynuowanie poszukiwań i wykorzystanie rozwiązań zastosowanych przez samego autora. Jednak znaczna część działań podejmowanych przez autora, jako część procesu twórczego, zwykle stanowiłaby niedopuszczalne przekroczenie kompetencji w wykonaniu konserwatora. Miejscowe wzmocnienie podobrazia, jak wspomniano wyżej, nie jest korzystne z punktu widzenia jego mechaniki. Dodatkowo realne wydaje się niebezpieczeństwo przeniknięcia żywicy w sposób niekontrolowany na lico (np. przez mikropęknięcia) podczas dolaminowywania wręg, co mogłoby spowodować nieodwracalne zniszczenie delikatnej, celulozowej powierzchni i leżącej na niej warstwy malarskiej, wykonanej farbami wodnymi. W podobraziach tych zachodzą niebezpieczne zmiany wywołane zastosowaniem materiałów konstrukcyjnych w sposób powodujący powstawanie pomiędzy nimi różnego rodzaju niekorzystnych oddziaływań. Laminat poliestrowo-ligninowy w normalnej temperaturze jest kruchy i nieelastyczny, w niższych temperaturach niezwykle wrażliwy, siatka stalowa zaś jest elastyczna i podatna na odkształcenia, stanowiąc rdzeń takiego laminatu, w przypadku odkształceń wywołuje naprężenia, powodujące pękanie i odspajanie.

w jaki artysta uformował podobrazie i jakość połączeń brytów, jeśli podobrazie nie jest wykonane $\mathrm{z}$ jednego kawałka siatki.

17 Patrz: S. A. Kamiński, Problematyka technologiczৃna... 
Rosnąca z czasem higroskopijność żywicy poliestrowej stwarza dla stalowej siatki zagrożenie korozyjne, a produkty korozji zwiększając objętość, rozsadzają i przebarwiają laminat i warstwę malarska.

Kompleksowe prace konserwatorskie i restauratorskie przy czterech obrazach Hors cadre: №38 (fot. 2, 3), №44 (fot. 4, 5), №53 (fot. 6, 7) przeprowadzono w latach 2009-2015 w ramach pracowni dyplomowej ${ }^{18}$ oraz №45 w ramach własnej praktyki konserwatorskiej. Obrazy te sa zróżnicowane pod względem wielkości, ale charakterystyczne dla cyklu pod względem budowy technicznej oraz występujących zniszczeń. Pochodzą ze zbiorów muzealnych i kolekcji prywatnych, trafiły do konserwacji ze względu na drastycznie pogarszający sie stan zachowania.

Bezpieczny przebieg prac konserwatorskich i restauratorskich przy tych dziełach umożliwiały różnego rodzaju podkładki odwzorowujące kształt odwrocia i lica. Na początku posługiwano się workami z piaskiem, odpowiednio złożonym płótnem bawełnianym, zawiniętą w folię poliestrową watą lub ligniną itp., jednak takie doraźne rozwiązania podczas długotrwałych prac okazały się niezadowalające i niewygodne. Zdecydowano więc o przygotowaniu „roboczych” podobrazi pomocniczych. Po przeprowadzeniu kilku prób $^{19}$ zdecydowano się na konstrukcję wykonaną z wysokogatunkowego, barwionego gipsu (różnice kolorystyczne kolejnych nakładanych warstw pomagały kontrolować ich równomierne rozprowadzenie na rozbudowanych przestrzennie powierzchniach) (fot. 8), zbrojonego gazą i drewnianymi krawędziakami (budowano z nich od odwrocia kratownice stabilizujące kształt) - po całkowitym wyschnięciu, z odpowiednia izolacja podobrazia te z powodzeniem służyły jako „stoły” utrzymujące pożądany kształt obrazów

\footnotetext{
18 Prace konserwatorskie wykonali studenci: Agnieszka Cwynar i Agata Warszewska pod kierunkiem prof. dr. hab. Dariusza Markowskiego i dr. Sławomira A. Kamińskiego z Zakładu Konserwacji i Restauracji Sztuki Nowoczesnej, UMK, Toruń, Polska.

19 M.in. próby z użyciem pianki poliuretanowej - Warszewska A. Podtoża konstrukcyjne dla obiektón niestabilnych, o niskiej sqtymności na praykktadzie Hors cadre nr 38 i 44 Alweksandra Kobzdeja, praca magisterska pod kier. prof. dr. hab. D. Markowskiego i dr. S. A. Kamińskiego, ZKiRSzN, UMK, Toruń 2009.
} 
i umożliwiały bezpieczna pracęe ${ }^{20}$ Zaletami takiej konstrukcji były: zadowalająca sztywność, stosunkowo niska masa, szybkość i prostota wykonania oraz, co istotne w wypadku roboczych podobrazi pomocniczych, bardzo niskie koszty ${ }^{21}$.

W przypadku Hors cadre №53 takie tymczasowe gipsowe podobrazie posłużyło również do wykonania gipsowej formy docelowego podobrazia pomocniczego.

Przy Hors cadre №45 jako robocze podobrazie pomocnicze posłużyło wykonane na podstawie skanu $3 \mathrm{D}^{22}$ pomocnicze podobrazie docelowe wyfrezowane $\mathrm{w}$ drewnie balsa. $\mathrm{Z}$ podobrazi pomocniczych korzystano, prowadząc prace przy wszystkich czterech obrazach.

Dla mających powstać docelowych podobrazi pomocniczych sformułowano kilka wymogów ${ }^{23}$ :

— żaden z elementów konstrukcyjnych nie może zakłócać ekspozycji (nie może być widoczny od strony lica);

- należy zapewnić nieinwazyjny dostęp do odwrocia pracy.

- materiały do budowy podobrazi powinny być neutralne chemicznie i biologicznie dla oryginału, zachowywać podobne odchyłki wymiarowe w zróżnicowanych warunkach wilgotnościowo-temperaturowych.

- sposób przeprowadzenia montażu i, w razie konieczności, demontażu nie może ingerować w strukturę obrazów w sposób nieodwracalny;

- podobrazia powinny charakteryzować się możliwie niska masa - jako trudny do osiagnięcia ideał przyjęto stosunek masy do powierzchni dzieł oryginalnych średnio $1,3 \mathrm{~kg} / \mathrm{m}^{2}$;

20 A. Warszewska, D. Markowski, S. A. Kamiński, Podtoża konstrukcyjne obiek.tów niestabilnych, o niskiej sztymności na pryyktadzie Hors cadre nr 38 i 44 Aleksandra Kobzdeja, „Ochrona Zabytków” 1-4:10-21, R. 2010.

${ }_{21}$ Ze względu na koszty kształt tych podobrazi był odwzorowywany z oryginalnych odwroci, w dwóch przypadkach do precyzyjnego rozłożenia warstwy izolującej - folii poliamidowej - użyto stołu dublażowego.

22 Skan wykonano w firmie QR Studio w Warszawie (www.qrstudio.pl).

23 Szerzej: S. A. Kamiński, M. Wachowiak, Conservation issues related to the use of auxiliary supports in the treatment of modern painting with untypical technical structures - as on works from the series Hors cadre by Aleksander Kobzdej, [w:] Current Technical Challenges in the Conservation of Paintings, Archetype Publications, London 2015, ss. 113-123. 
- uzyskane usztywnienie oryginalnego podobrazia powinno ograniczyć jego odkształcenia w sposób wykluczający dalsze pękanie laminatu wywołane deformacjami kształtu.

Kierując się powyższymi założeniami, jako najwłaściwsze materiały preferowano: laminaty poliestrowe i epoksydowe z włóknami szklanymi i węglowymi, w dalszej kolejności poliwęglan, aluminium, stal nierdzewną i drewno, ale najistotniejszym czynnikiem wpływającym na wybór materiału pozostawały indywidualne cechy podobrazi konkretnych obrazów.

W wyniku poszukiwań i prób ${ }^{24}$ wytypowano do realizacji cztery różne konstrukcje, pierwsze dwie do mniejszych prac o sztywniejszych podobraziach, kolejna do podobrazia o bardzo niskiej sztywności (mimo niewielkiego formatu i masy) oraz ostatnia - do obrazu o znacznej powierzchni, stosunkowo wysokiej masie i bardzo niskiej sztywności. Starano się zastosować rozwiązania indywidualne, dostosowane do kształtu i wielkości obrazów. Zróżnicowanie konstrukcji podobrazi pomocniczych ma również ten walor, że pozwala na porównywanie osiagniętych efektów.

Do obrazu Hors cadre №38, którego średnia grubość podobrazia wynosiła $4 \mathrm{~mm}$, a powierzchnia $1,12 \mathrm{~m}^{2}$, masa $1,55 \mathrm{~kg}$, wykonano podobrazie z siatki aluminiowej cięto-ciagnionej, przymocowanej do drewnianej kratownicy. Ciężar konstrukcji wyniósł $2 \mathrm{~kg}$ (fot. 9, 10, 11). Do montażu podobrazia wykorzystano: autorskie zawieszki (wlaminowane pętelki z drutu) oraz oczka siatki, przez które możliwe było przetykanie drutu. Konstrukcja ta ułatwiła bezpieczny, bezkontaktowy z partiami oryginalnymi transport obrazu, cechuje się pożądaną sztywnością i pozostawia odsłonięta część odwrocia. Wadą tego rozwiązania jest nieprecyzyjne odwzorowanie kształtu oryginału i fragmentaryczne zabezpieczenie oryginalnego podobrazia, a także masa konstrukcji wyższa od masy oryginału ${ }^{25}$.

\footnotetext{
${ }^{24}$ Szerzej - A. Warszewska, „Podłoża konstrukcyjne...”, praca magisterska.

25 A. Warszewska, „Dokumentacja prac konserwatorskich i restauratorskich: obraz nr 38 z cyklu Hors cadre, Aleksander Kobzdej, 1971, pracownia artysty", praca dyplomowa ZKiRSzN, UMK, Toruń, 2009
} 
W obrazie Hors cadre №44, którego średnia grubości wynosiła $6 \mathrm{~mm}$, powierzchnia $1,08 \mathrm{~m}^{2}$, a masa $1,40 \mathrm{~kg}$, zastosowano podobrazie z płyty poliwęglanowej o strukturze komorowej z drewnianą wręga konstrukcyjna, spełniająca rolę łącznika przymocowanego do oryginalnej „kobzdejowskiej” wręgi (fot. 12). Ciężar konstrukcji wyniósł 1,3 kg. Tak jak w poprzednim obrazie do zamontowania podobrazia użyto autorskich zawieszek oraz tych oczek oryginalnej siatki, przez które możliwe było przetkanie drutu i wykonanie połączenia. Podobrazie to cechuje masa niższa od masy obrazu, przezroczystość i wysoka sztywność. Przenoszenie obrazu jest trudniejsze niż w pierwszym przypadku, ale z pewnością o wiele bezpieczniejsze niż bez podobrazia pomocniczego. Obawy mogą budzić: stabilność kształtu drewnianej wręgi, właściwości elektrostatyczne płyty i związane z tym ryzyko zwiększenia ilości kurzu w bezpośredniej bliskości obrazu oraz, tak jak w poprzednim przypadku, tylko częściowe osłonięcie odwrocia obrazu ${ }^{26}$.

Obraz Hors cadre №45, o średniej grubości podobrazia 3,5 mm, powierzchni $0,48 \mathrm{~m}^{2}$ i masie $790 \mathrm{~g}$, otrzymał podobrazie pomocnicze wykonane $z$ frezowanej i usztywnionej przez impregnację paraloidem B-72 w toluenie płyty z drewna balsa, przymocowanej do oryginalnego podobrazia za pomoca magnesów neodymowych. Podobrazie to w swoim zamyśle ma spełniać funkcję usztywniająca i, stanowiąc jednocześnie barierę wilgotnościowo-temperaturową, stabilizować oryginalne podobrazie.

Ze względu na duży format obrazu i prostokątny kształt podobrazia najbardziej zaawansowanym technicznie projektem wydaje się wykonanie podobrazia pomocniczego do obrazu Hors cadre №53. Średnia grubość jego podobrazia wynosiła $3 \mathrm{~mm}$, powierzchnia $2,25 \mathrm{~m}^{2}$, a masa 2,9 kg, Zdecydowano się więc na sprawdzenie innych możliwości, pozwalających bez nieodwracalnych ingerencji utrzymać stabilność kształtu obrazu, czerpiąc z rozwiązań stosowanych min. przy wykonywaniu podłoży zastępczych dla malowideł ściennych, szczególnie wykorzystują-

26 Ibidem. 
cych laminatowe konstrukcje przekładkowe ${ }^{27}$. Produkcja wyrobów z laminatów np. poliestrowych wymaga na pewnych etapach stabilizowania kształtu poszczególnych elementów. W tym celu stosuje się specjalnie zaprojektowane łoża montażowe. Również ta procedura była inspiracja do zaprojektowania i wykonania omawianych podobrazi pomocniczych. W tym przypadku zdecydowano się wykonać je z materiału pokrewnego oryginałowi, czyli również z laminatu. Aby osiagnać wysokie parametry techniczne zdecydowano się na zastosowanie rzadkiej w ochronie zabytków techniki wykonania samego podobrazia - infuzji oraz użycie materiałów umożliwiających otrzymanie jak najwyższych parametrów.

Technika infuzji jest to proces, podczas którego osiagane jest podciśnienie w obszarze pomiędzy formą i workiem próżniowym lub membraną. Ta różnica w ciśnieniu powoduje zassanie żywicy i wciągnięcie jej w materiał rdzeniowy (np. tkaninę szklaną, aramidową lub węglowa). Jest procesem najbardziej zaawansowanym technologicznie spośród metod wytwarzania laminatów, jak również pozwalającym na uzyskanie najkorzystniejszego stosunku masy zbrojenia do masy żywicy, co wiąże się z uzyskaniem lepszych własności mechanicznych i wytrzymałościowych. Infuzja próżniowa (VI - ang. Vacuum Infusion, RI - ang. Resin Infusion) razem z nasycaniem ciśnieniowo-próżniowym RTM (ang. Resin Transfer Molding) należy do rodziny procesów LCM (ang. Liquid Composite Molding), których istotą jest przesycanie ciekłą żywicą suchego zbrojenia umieszczonego w zamkniętej formie. W literaturze oraz w terminologii infuzja funkcjonuje pod wieloma nazwami ${ }^{28}$.

27 Szczegółowo opisano rozwój, najkorzystniejsze rozwiązania konstrukcyjne i mechanikę takich podobrazi w R. Rogal, J. Mrowińska, M. Roznerska, Zastosowanie wtókien firet coremat do wykonania podtoży zastepcsych dla przenoszonych malowidet ściennych sgraffit $i$ mozaik.

28 Producenci chcą uniknąć wysokich opłat licencyjnych za używanie opatentowanych technologii i próbuja modyfikować oraz doskonalić proces, wprowadzając przy tym własną nazwę. Związane jest to z dużymi możliwościami modyfikacji procesu i sposobu jego realizacji oraz z regulacjami prawnymi. 
Do najbardziej rozpowszechnionych należą:

- VIP - Vacuum Infusion Process,

- RIFT - Resin Infusion under Flexible Tooling,

- SCRIMP - Seemann Composites Resin Infusion Molding Process,

- VARTM - Vacuum Assisted Resin Transfer Moulding,

- VARIM - Vacuum Assisted Resin Infusion Moulding,

- VBRTM - Vacuum Bag Resin Transfer Moulding,

- LoWaRI - Low Waste Resin Infusion,

- CVI - Controlled Vacuum Infusion / Injection,

- VIM - Vacuum Infusion Molding,

- CCBM - Closed Cavity Bag Molding.

Początki infuzji datowane są na lata 50. XX wieku. Pierwsze zastosowanie znalazła w produkcji kompozytów na potrzeby lotnictwa wojskowego, a następnie NASA. W ciagu ostatnich dziesięciu lat widoczny jest znaczny wzrost zainteresowania tą technologia w budowie już nie tylko samolotów, ale i jachtów, łodzi motorowych, łopat elektrowni wiatrowych i wielu innych elementów. Laminowanie metodą infuzji przebiega następująco: na przygotowanej formie układane są wszystkie elementy późniejszego wyrobu kompozytowego wraz z systemem rozprowadzania żywicy i niezbędnymi ze względów technologicznych między warstwami (niezbędnym elementem technologii jest zapewnienie swobodnego transportu żywicy przez strukturę laminatu - osiaga się to poprzez zastosowanie odpowiednio perforowanego materiału przekładkowego, tkaniny z włókna jednokierunkowego lub specjalnej siatki), układ ten jest uszczelniany, następnie wytwarzane jest podciśnienie (w zaawansowanych systemach wartość podciśnienia jest mierzona), do układu wprowadzana jest żywica o odpowiednich parametrach, która przesyca wszystkie elementy zbrojenia (sklejone uprzednio ze sobą w celu uniknięcia w trakcie laminowania niekontrolowanych przemieszczeń i deformacji). Różnica ciśnień pomiędzy wnętrzem formy a ciśnieniem atmosferycznym powoduje docisk worka w kierunku formy i wzrost upakowania zbrojenia. Proces prowadzi się aż do całkowitego wysycenia materiału zbrojącego wprowadzaną żywica. Jako zbrojenie szczególnie polecane jest stosowanie multiaxialnych tkanin lub matotkanin 
szytych dedykowanych do procesu infuzji, gdyż ich specjalna konstrukcja ulepsza proces płynięcia żywicy oraz pozwala na mniejsze jej zużycie. Bardzo często w procesie celem zwiększenia grubości laminatu przy jednoczesnym zachowaniu odpowiednio niskiej masy oraz własności wytrzymałościowych stosowane są materiały przekładkowe w postaci drewna balsa, pianek PVC, PET czy plastrów miodu. W porównaniu z tradycyjnymi metodami wykonywania wyrobów kompozytowych uzyskujemy: dokładniejsze odwzorowanie oraz korzystniejszy stosunek ilości żywicy do zbrojenia, co w znacznym stopniu podnosi parametry konstrukcyjne i obniża masę produktu. Dodatkowo istnieje możliwość przesycenia wielu warstw $\mathrm{w}$ jednym procesie - co zmniejsza prawdopodobieństwo wytworzenia się pęcherzy ${ }^{29}$.

W omawianym przypadku metoda infuzji wykonano laminat epoksydowo-węglowy z rdzeniem ze sphertexu, co pozwoliło na odwzorowanie kształtu tak dużego podobrazia z zadowalająca dokładnością, wysoką sztywnościa, przy nieznacznej grubości i masie. Ciężar podobrazia pomocniczego wyniósł 4,8 kg. Masa podobrazia jest niestety półtorakrotnie wyższa niż masa obrazu - co jest związane z koniecznością zapewnienia odpowiedniej sztywności przy tak dużym formacie (fot. 13-17). Do przymocowania podobrazia pomocniczego wykorzystano, tak jak we wcześniejszych realizacjach niezalaminowane przez autora oczka siatki oryginału - miejsc takich, rozmieszczonych dosyć regularnie, znaleziono kilkadziesiąt (obraz nie posiadał autorskich zawieszek ${ }^{30}$ ) (fot. 18). Ze względu na pokaźne rozmiary obrazu konieczne było opracowanie systemu bezpiecznej ekspozycji, przechowywania i transportu obrazu w tym celu zamontowano do kratownicy podobrazia pomocniczego dwa rodzaje specjalnych uchwytów oraz kratownicę z drewna balsa. Podobrazie

$29 \mathrm{Na}$ podstawie: M. S. Koefeld, Modeling and Simulation of the VARMT Process for Wind Turbine Blades, Industrial Ph. D. Dissertation, Aalbor g University, 2003, za: http://www. laminaty-wentech.pl/18.10.2015

30 W galerii po prostu przebijano lico w kilku miejscach i przetkano drut umożliwiający wieszanie pracy. 
pomocnicze jest nieprzezroczyste, w związku z czym naklejono na nie zdjęcie odwrocia informujące o jego wyglądzie ${ }^{31}$ (fot. 19).

Opisane powyżej próby przeprowadzone w latach 2008-2015 pozwoliły uzyskać zamierzone efekty oraz zdobyć nowe doświadczenia w pracy $\mathrm{z}$ tak niestabilnymi wymiarowo obrazami, jednak żadne z rozwiązań nie było w pełni zadowalające. Przy większej dostępności zaawansowanej techniki do odwzorowywania kształtu używamy obecnie skanerów $3 \mathrm{D}^{32}$, a podobrazia pomocnicze do obrazów z cyklu Hors cadre frezujemy w wybranym materiale na frezarkach $\mathrm{CNC}$ - ten temat wykracza poza ramy niniejszego artykułu - jednak do znalezienia idealnego rozwiązania wydaje się wciąż jeszcze daleko.

Pozostałe problemy konserwatorskie jak: powstrzymanie procesów korozji, usunięcie wiążących się z nią przebarwień, przywrócenie spójności poszczególnym warstwom, uzupełnienie ubytków: siatki, laminatu oraz warstwy malarskiej również zostały rozwiązane w trakcie prowadzonych w ramach zajęć studenckich prac dyplomowych i magisterskich oraz $\mathrm{w}$ ramach własnych badań ${ }^{33}$.

\section{Summary}

\section{Construction of auxiliary supports using infusion technic based on picture of Aleksander Kobzdej „Hors cadre no. 53”}

In the paper results of investigation of: technical structure, state of preservation, reasons of deterioration and the undertaken conservation restoration treatment of works of artist Alexander Kobzdej (1920-1972) will be presented.

In the cycle Hors Cadre from 1971 Kobzdej redefined the function of the individual elements consisted in the traditional easel painting. As in his earlier work

\footnotetext{
31 A. Cwynar, Dokumentacja prac konserwatorskich i restauratorskich..., op. cit

32 S. A. Kamiński, Remarks on the ways of documentation of the structure and state of preservation and on the methods of conservation research of the works of modern art, [w:] D. Markowski, S. A. Kamiński, M. Wachowiak, Issues of conservation and restoration of modern and contemporary art, Toruń 2010, ss. 15-31.

33 Prace przy obrazie Hors cadre nr 45 wykonano nieodpłatnie w ramach prowadzonych badań.
} 
he incorporated the space into the construction of his paintings, yet in this case their technical structure is totally irrelevant to the traditional easel painting studio practice. The support is made of 3D shaped metal wire net, being core for the polyester-lignite laminate, made in a way enabling application of the water based medium paint layer on its top.

For the reason of their structure, these - as it appeared very sensitive paintings - became a challenge for the conservator - restorer. Within the Ph.D. dissertation, M.A. thesis as well as through practical diploma works executed in our Department the research conducted on them let to propose guidelines of conservation care for these objects as well as conservation-restoration treatments. One of the main problem it appeared to be the unstable character of their supports, making safe storing, transport and exposition impossible. It was necessary to develop individually dedicated auxiliary supports for each work. Materials used were, among others: polycarbonates, aluminium wire nets, epoxy-polycarbonate laminates made by the infusion technique). The auxiliary supports made in different techniques let significantly slowing down the unwanted changes in the paintings structure, the methodology of the local repairs of the original support was developed, meaning filling in the losses of the polyester laminate and of extremely matt paint layer surface.

Gained experience can be used during conservation of the other paintings of the cycle Hors Cadre (about seventy works), certain elements of former cycle (Clefts), and of other paintings in which analogical materials were used. 
[552]

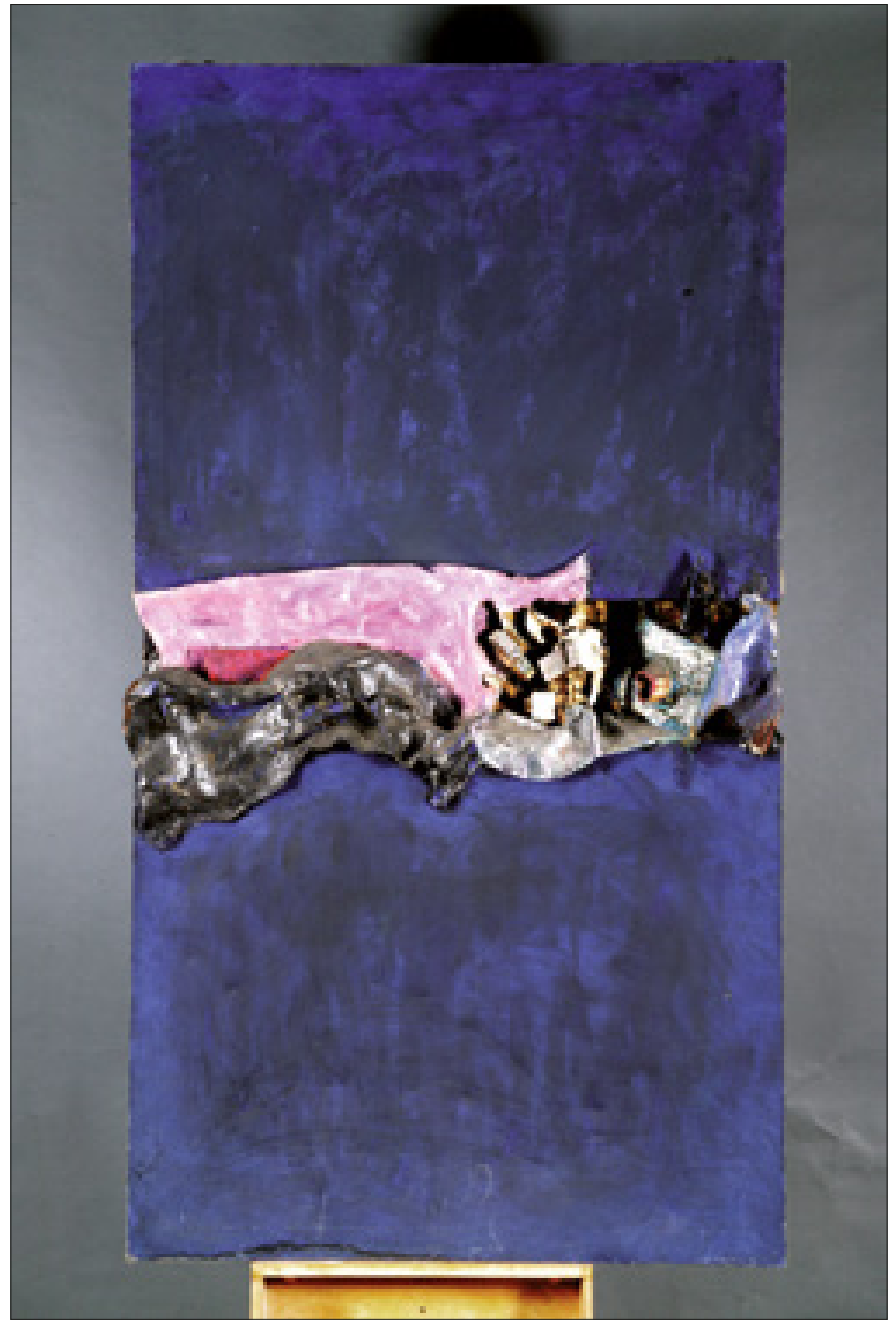

1. A. Kobzdej, Szuczelina w czarno-niebieskim, Muzeum Okręgowe w Toruniu (fot. S. A. Kamiński) 
[553]

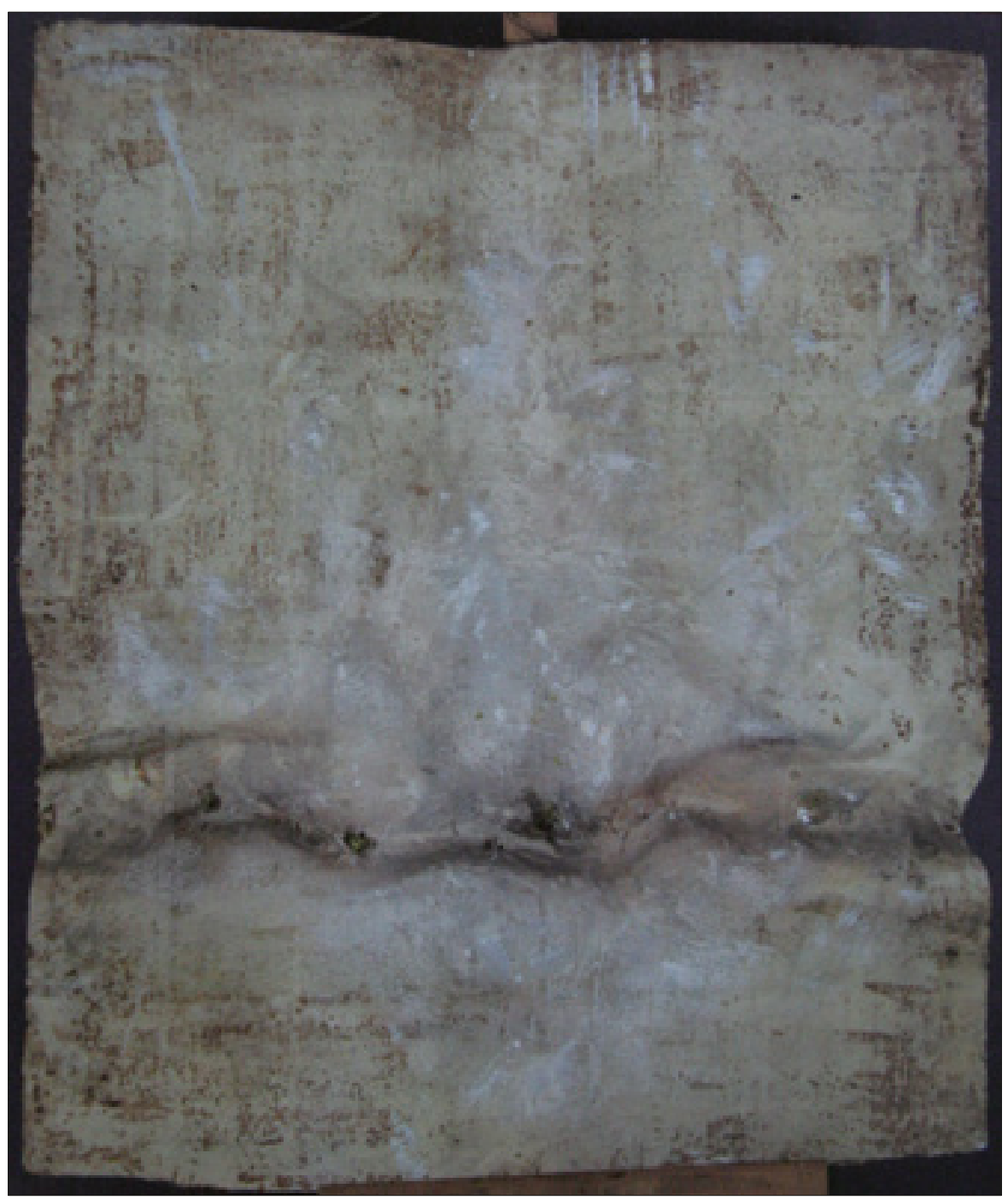

2. A. Kobzdej, Hors cadre no. 38, własność prywatna, lico po konserwacji (fot. A. Warszewska) 
[554]

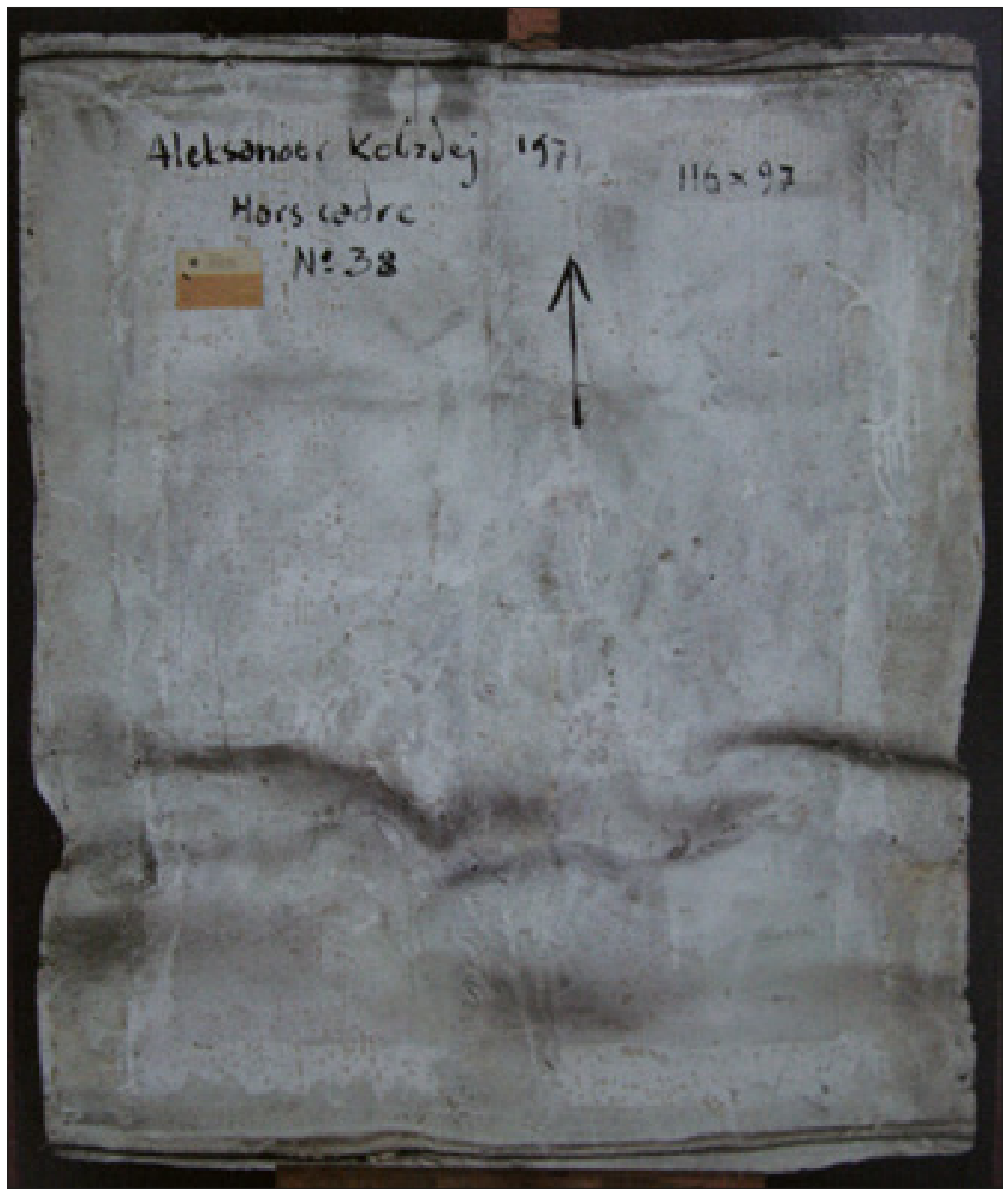

3. A. Kobzdej, Hors cadre no. 38, odwrocie po konserwacji (fot. A. Warszewska) 


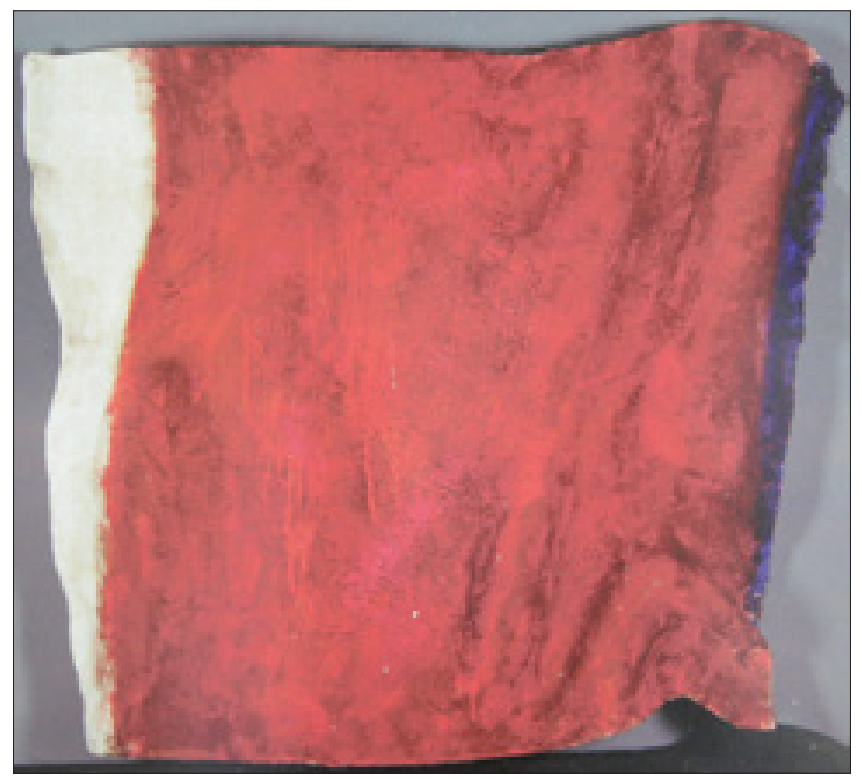

4. A. Kobzdej, Hors cadre no. 44, własność prywatna, lico po konserwacji (fot. A. Warszewska)

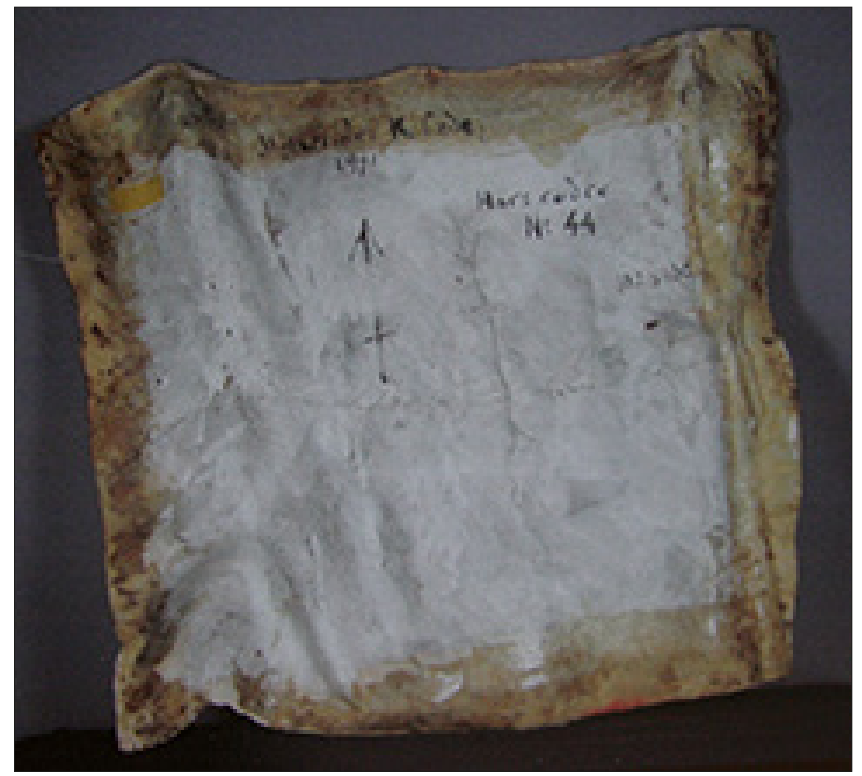

5. A. Kobzdej, Hors cadre no. 44, odwrocie po konserwacji (fot. A. Warszewska) 
[556]

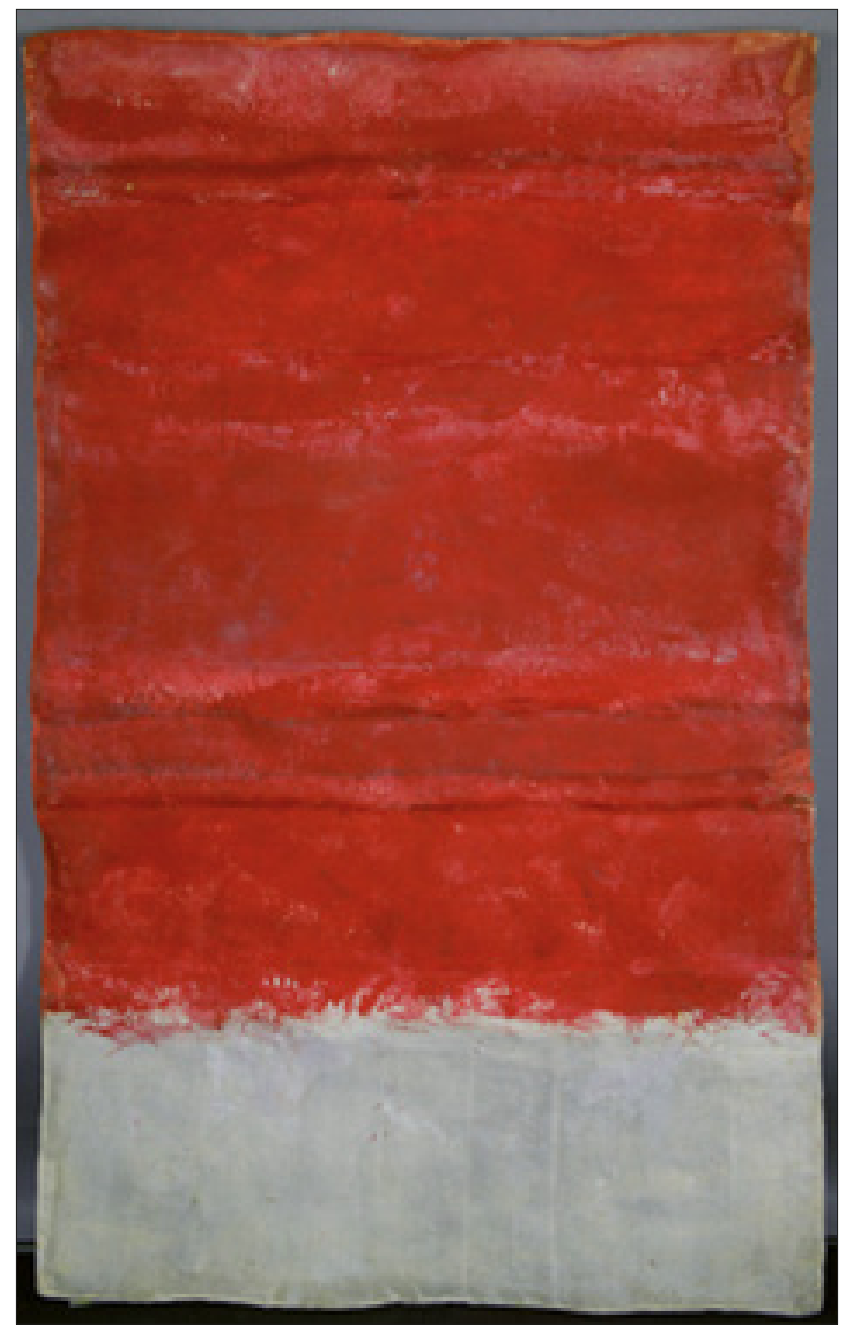

6. A. Kobzdej, Hors cadre no. 53, Muzeum Okręgowe im. Leona Wyczółkowskiego w Bydgoszczy, lico po konserwacji (fot. A. Cwynar) 


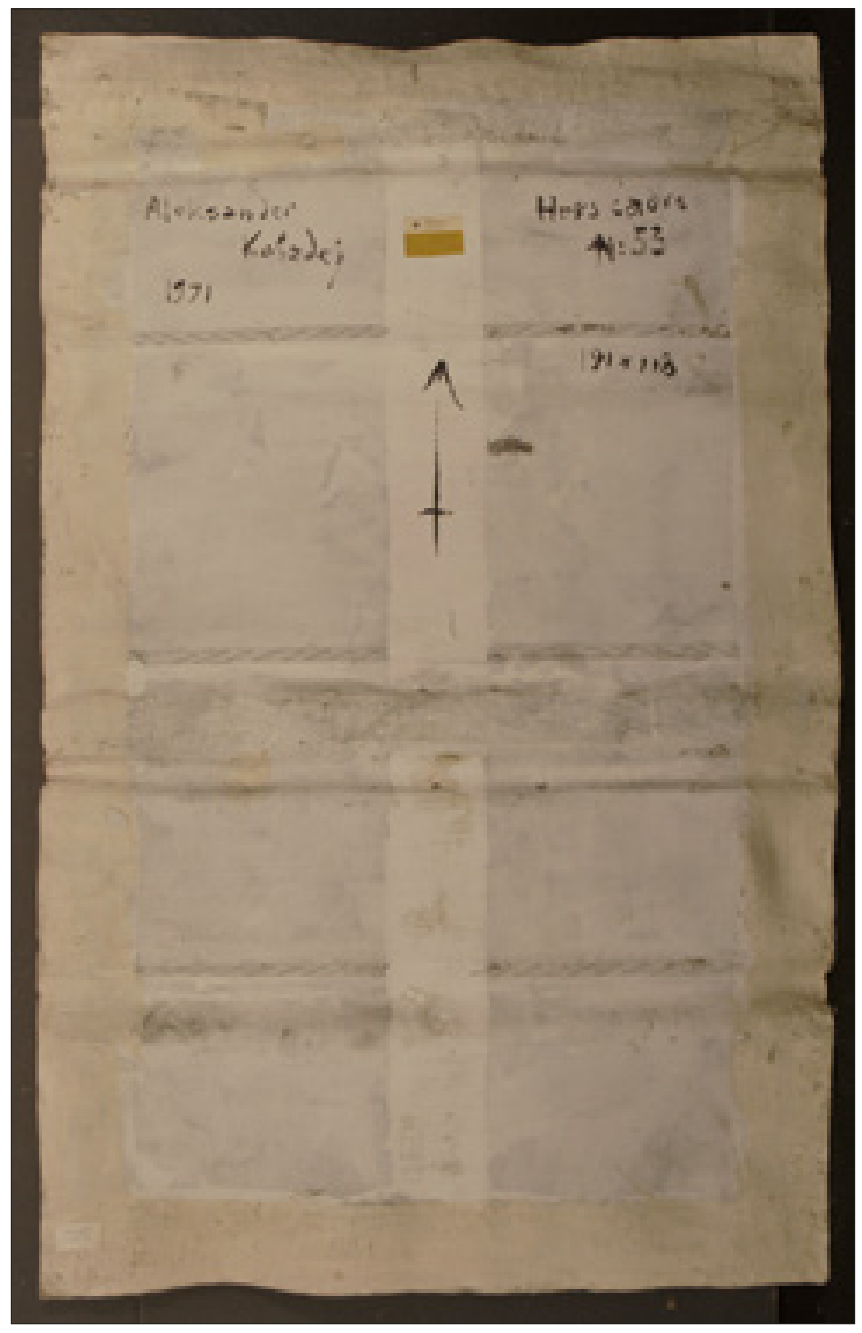

7. A. Kobzdej, Hors cadre no. 53, odwrocie po konserwacji (fot. A. Cwynar) 
[558]

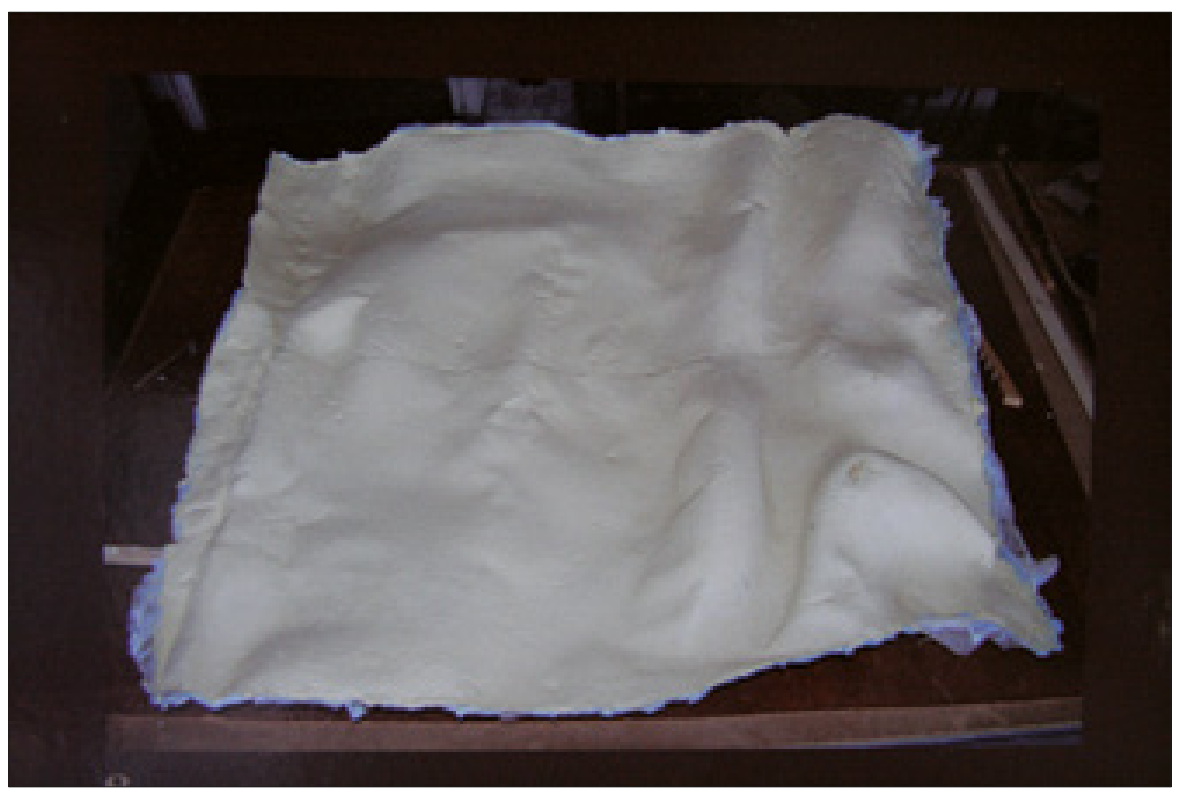

8. Gipsowe podobrazie pomocnicze do Hors cadre no. 44 (fot. A. Warszewska) 


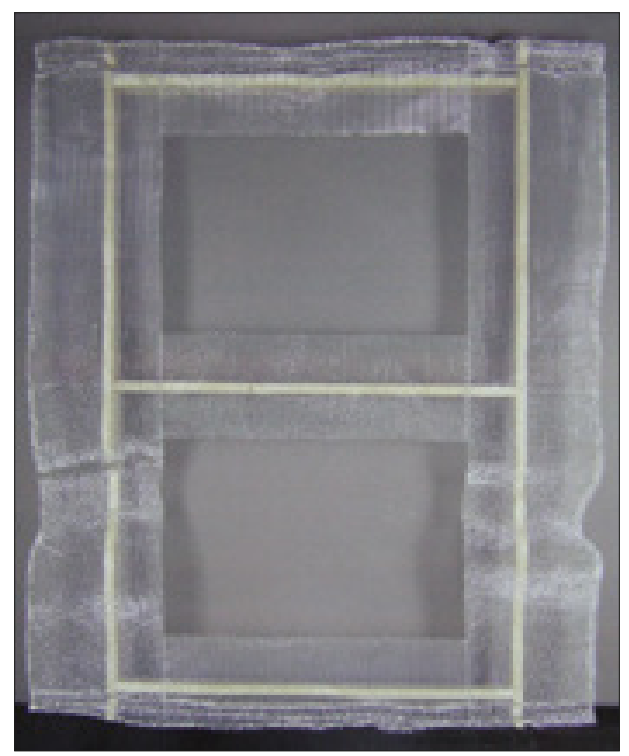

9. Podobrazie pomocnicze do Hors cadre no. 38 wykonane $\mathrm{z}$ drewnianej ramy i aluminiowej siatki cięto-ciagnnionej (fot. A. Warszewska)

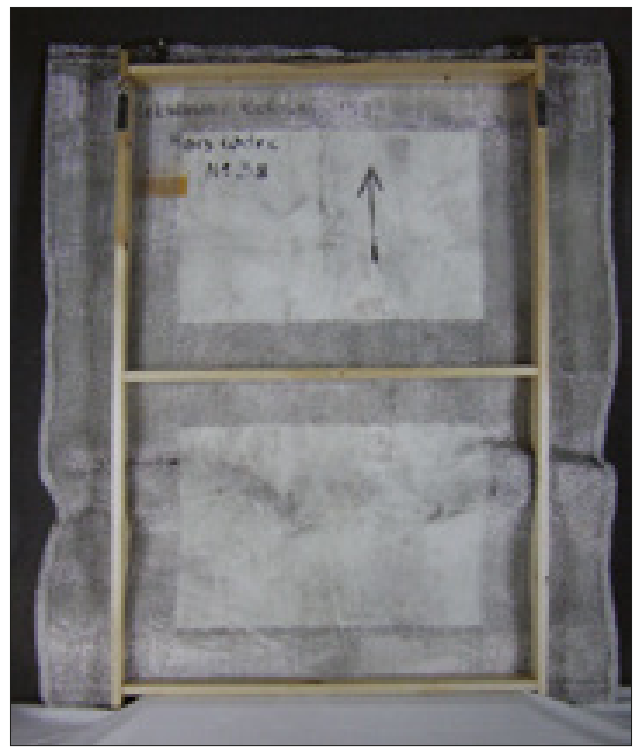

10. Widok odwrocia Hors cadre no. 38 po zamocowaniu podobrazia pomocniczego (fot. A. Warszewska) 


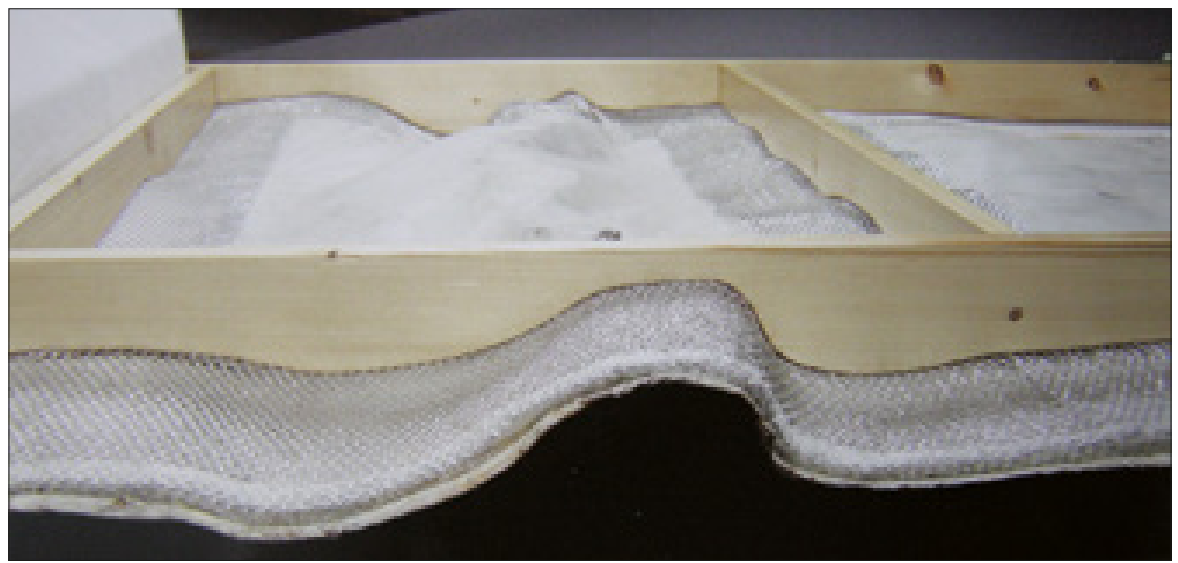

11. Podobrazie pomocnicze Hors cadre no. 38 - fragment - odwzorowanie kształtu obrazu (fot. A. Warszewska)

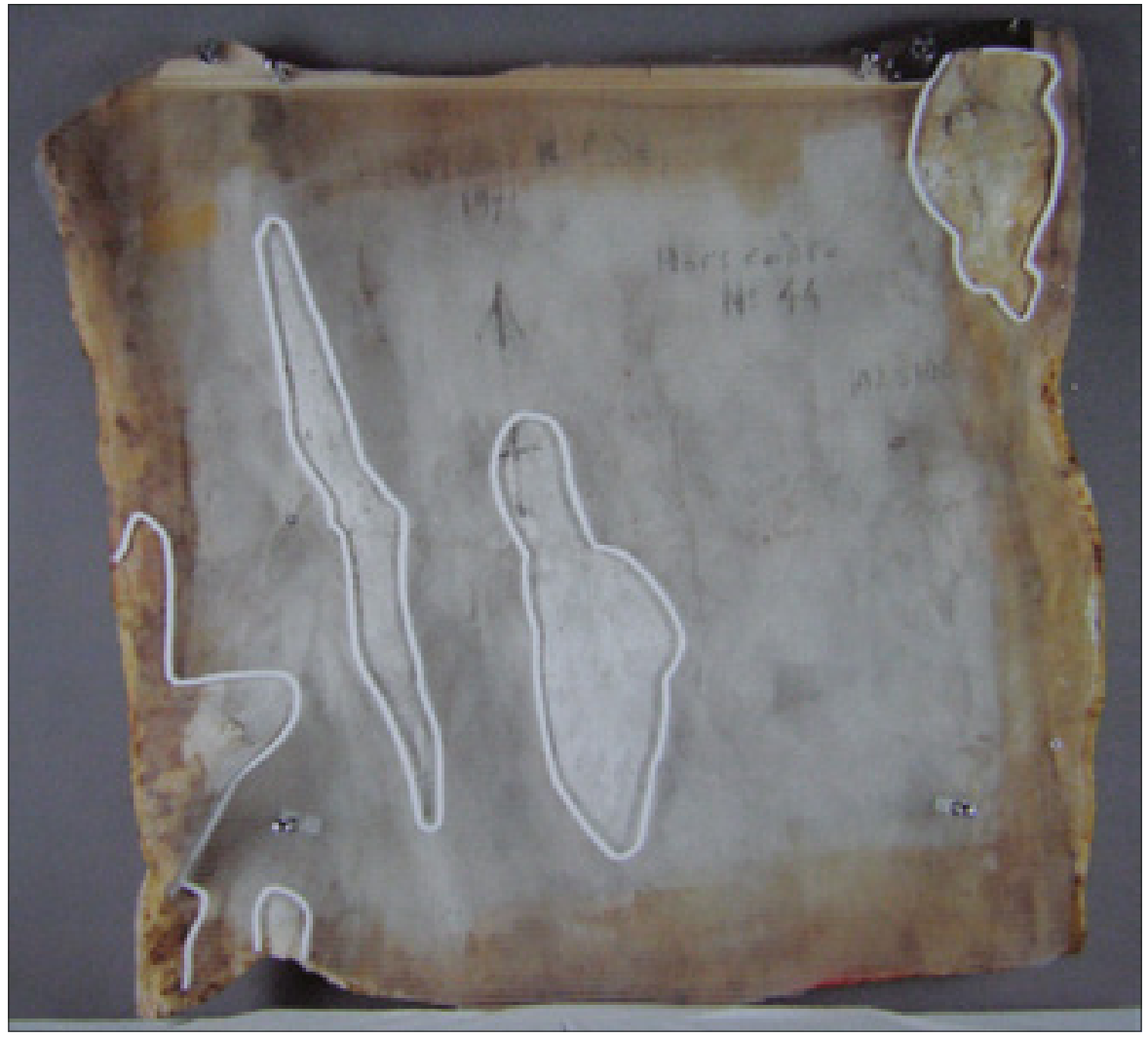

12. Podobrazie pomocnicze do Hors cadre no. 44 wykonane z poliwęglanu komorowego widok od odwrocia (fot. A. Warszewska) 


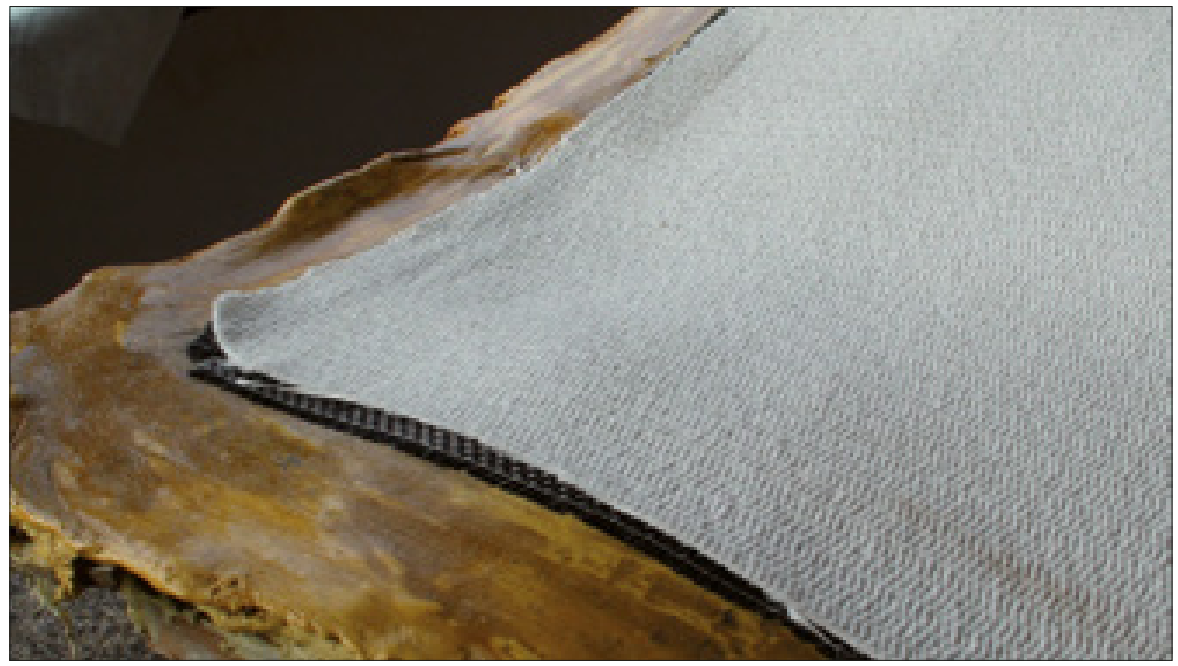

13. Przygotowanie do infuzji - doklejanie warstwy Spheretxu (fot. S. A. Kamiński)

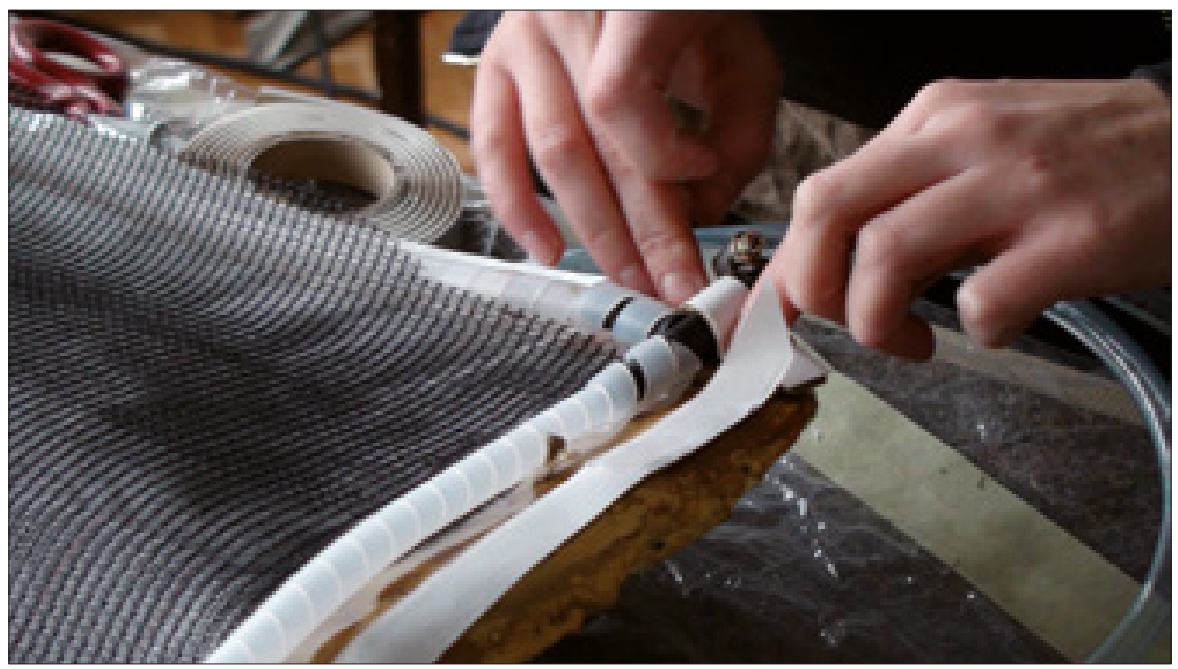

14. Przygotowanie do infuzji - rurki spiralne doprowadzające żywicę do zbrojenia (fot. S. A. Kamiński) 


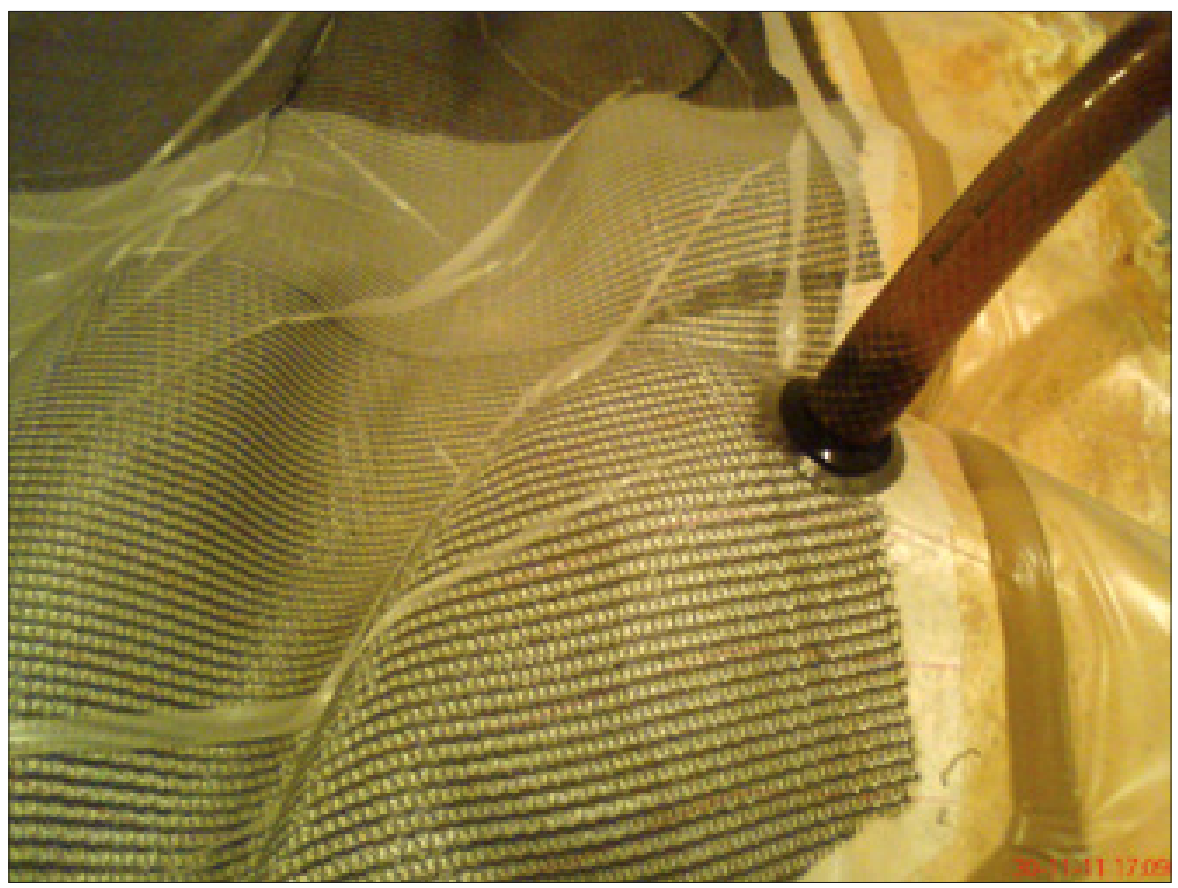

15. Infuzja - system doprowadzający żywicę (fot. S. A. Kamiński)

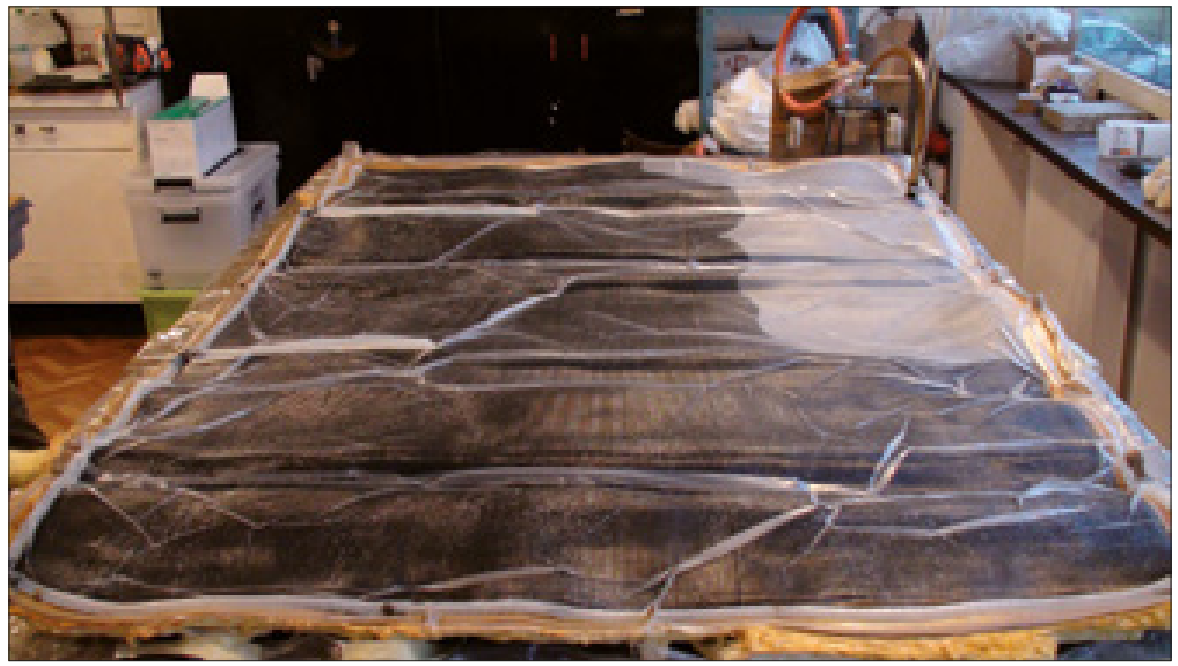

16. W trakcie impregnacji zbrojenia żywicą metodą infuzji (fot. S. A. Kamiński) 


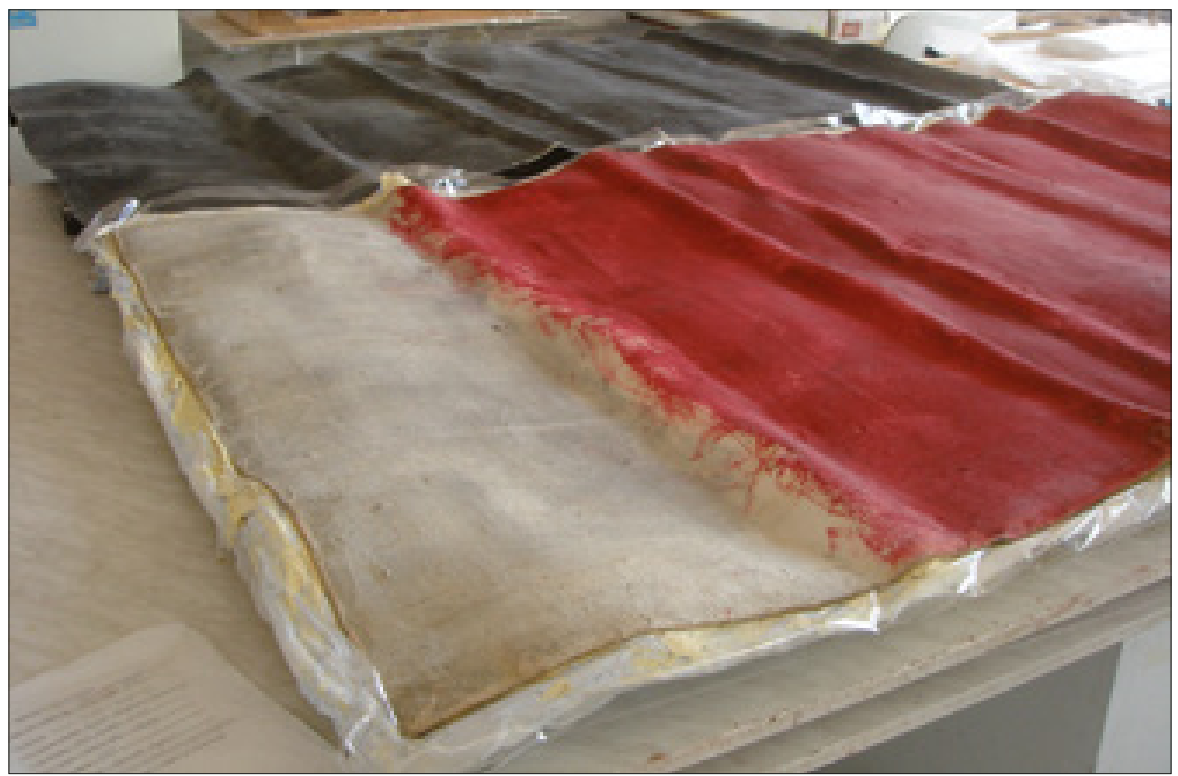

17. Porównanie odwzorowania kształtu obiektu przez laminat (fot. S. A. Kamiński)

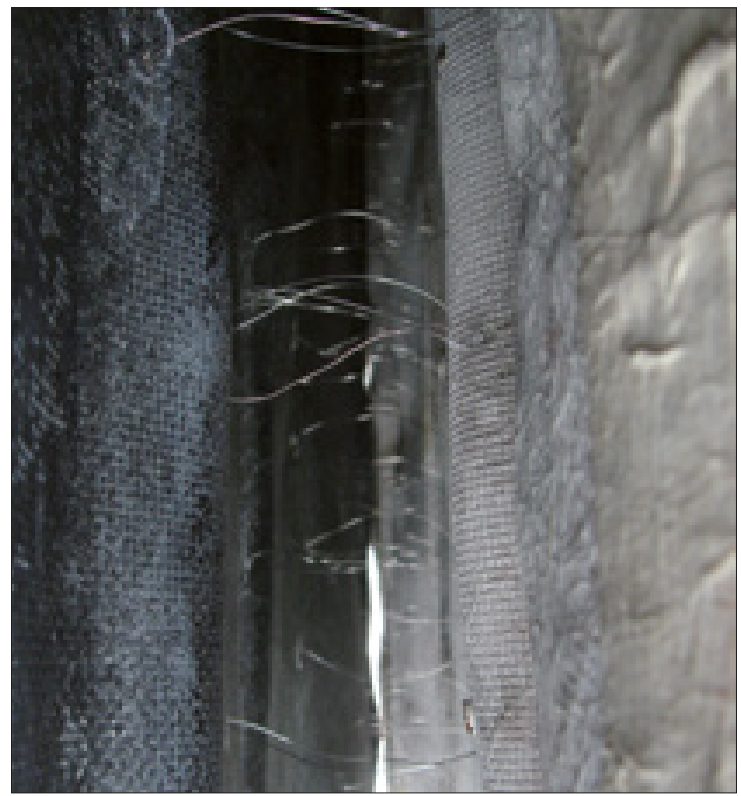

18. Przeplatanie drucików mocujących obiekt na laminacie (fot. S. A. Kamiński) 
[564]

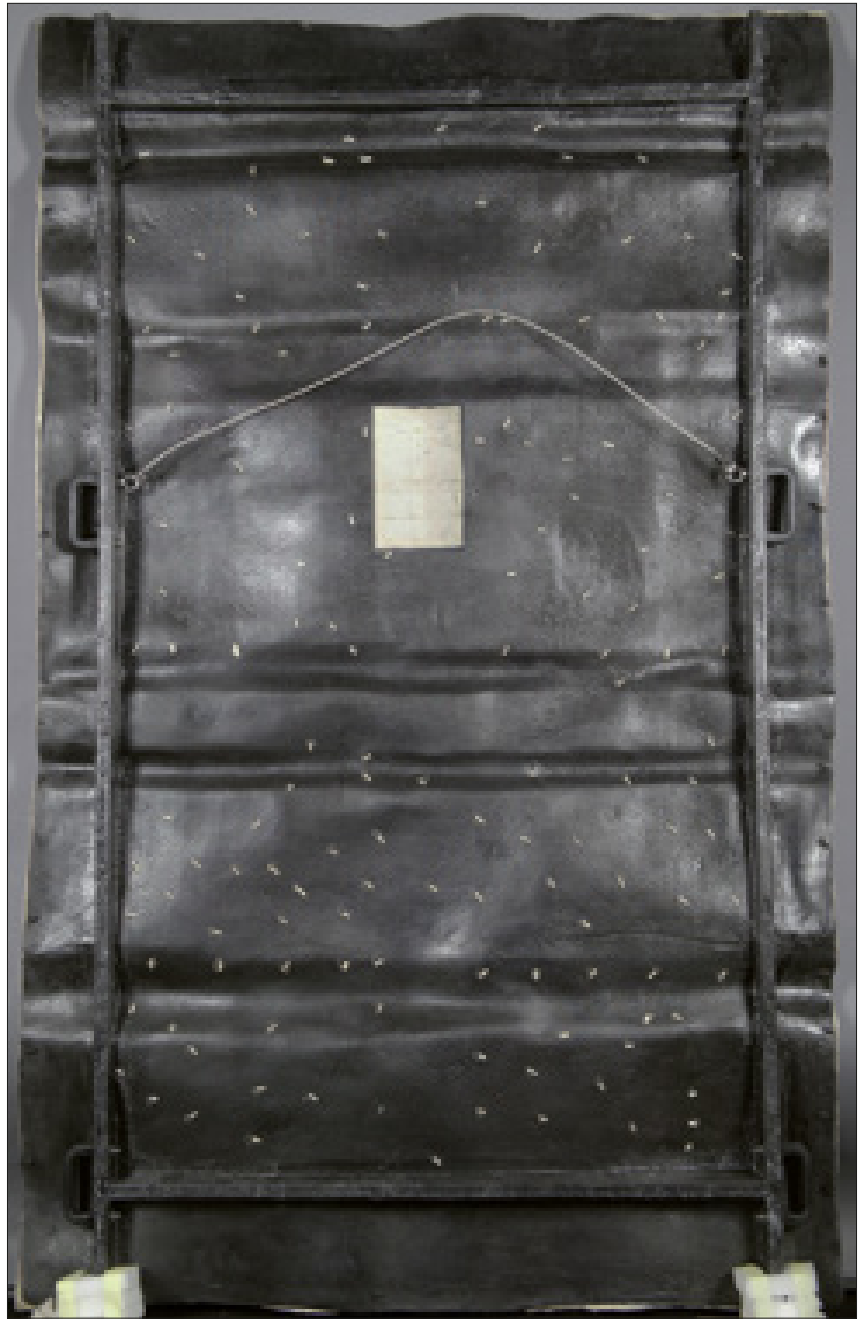

19. Odwrocie obiektu po konserwacji - widoczne podobrazie pomocnicze z widocznymi miejscami przeplotu drucików mocujących (fot. A. Cwynar) 